УДК 341.171: 341.217(4)

DOI https: / / doi.org/10.32837 / yuv.v0i6.2052

\author{
Я. Костюченко, \\ доктор юридичних наук, адвокат, \\ кафедра порівняльного і європейського права \\ Інституту міжнародних відносин \\ Київського національного університету імені Тараса Шевченка
}

\title{
МІЖНАРОДНО-ПРАВОВІ АСПЕКТИ ОХОРОНИ ІНТЕЛЕКТУАЛЬНОСТІ ВЛАСНОСТІ: ДОСВІД, ПРАВОВЕ РЕГУЛЮВАННЯ, ПЕРСПЕКТИВИ ДЛЯ НАЦІОНАЛЬНОЇ ПРАКТИКИ
}

\begin{abstract}
Постановка проблеми. Одними 3 найдавніших правил поведінки вважаються норми, що стосуються захисту інтелектуальної власності, адже власність завжди була невід’ємним атрибутом добробуту, впливу та влади. 3 огляду на це увага до зазначеного інституту завжди домінувала як на рівні окремих держав, так i на рівні субрегіональних утворень. 3 розвитком інформаційних правовідносин та інформаційно-комунікаційних технологій правова охорона інтелектуальної власності теж значно модернізувалась, адже змінилася концепція юридичної відповідальності, виникли нові правовідносини, нові об'єкти правової охорони тощо. Однією з актуальних проблем у зазначеному контексті стала конкуренція міжнародно-правових норм. У межах, зокрема, Всесвітньої організації інтелектуальної власності (ВОІВ), з одного боку, спостерігається рух у напрямі укладання нових угод про захист інтелектуальних прав, таких як Пекінський договір з аудіовізуальних виконань (Treaty for audiovisual performers) 2012 p. [1]; Женевський акт до Лісабонської угоди про охорону географічних зазначень (Geneva act of the Lisbon agreement to protect geographical indications (Gis)) [2], підписаний у травні 2015 р.; триває
\end{abstract}

робота над договором про захист прав суб'єктів мовлення. 3 іншого боку, з'являються ініціативи й механізми захисту інтересів користувачів, а саме Марракеський договір про доступ для незрячих і слабозорих 2013 p. (Marrakesh treaty providing access to visually impaired users) [3]; продовжується робота над договором про архіви та бібліотеки. Внаслідок цього виникають ускладнення правозастосування, особливо в умовах, коли використання об'єктів правової охорони відбувається переважно онлайн. До того ж підписуються регіональні угоди про торгівлю, що додають нові норми, зазвичай на користь правовласників. Норми різних угод суперечать одна одній; часом вони навмисно обмежують країнам-учасницям поле для маневру, буває, що для дотримання одного міжнародного договору країна змушена порушувати інший. Співвідношення між нормами різних конвенцій заплутані, наприклад, суперечать одна одній умови, за яких географічне зазначення перетворюється на родове позначення щодо Угоди про трансатлантичне партнерство (Transpacific partnership agreement (TPP)) і щодо Женевського акта до Лісабонської угоди.

У контексті зазначеного вище привертає до себе увагу думка професора 
дослідницького Університету Вандербільта Даніеля Жарве про те, що нині у сфері інтелектуальної власності постійно з'являються як нові права і способи їхнього захисту, так і нові винятки й обмеження прав, і кожен крок назустріч інтересам однієї сторони означає втрати для іншої [4].

Аналіз останніх досліджень i публікацій. В основу написання публікації покладено аналіз міжнародно-правових норм, міжнародне та національне законодавство у сфері правової охорони інтелектуальної власності, а також творчий добуток таких відомих українських та зарубіжних учених, як Д. Жерве [4], В. Муравйов [6], О. Кадєтова [7], А. Жак [8], О. Орлюк [9].

Метою статті $€$ теоретико-правовий аналіз міжнародно-правового регулювання інтелектуальної власності. Для реалізації визначеної мети передбачається вирішення таких дослідницьких питань:

- загально-теоретичний аналіз правового забезпечення охорони інтелектуальної власності у контексті європейської інтеграції України;

- дослідження досвіду окремих країн правового захисту інтелектуальної власності;

- розроблення пропозицій, придатних для імплементації у національний досвід.

Виклад основного матеріалу. Всеосяжний характер Зони вільної торгівлі (ЗВТ) між Україною та ЄС полягає саме в тому, що вона стосується правового режиму доступу не тільки до ринку товарів, але й послуг, зокрема передбачається наближення законодавства України до права ЄС у супутніх сферах, які $€$ ключовими для вільної торгівлі. Разом з умовами (та обумовленостями) доступу до внутрішнього ринку ЄC в Угоді про асоціацію між Україною та Європейським Союзом [5] (далі - Угода про асоціацію) прописані докладні процедури для забезпечення однакового тлумачення та застосування єдиного законодавства ЄС. Це стосується, зокрема, такої сфери, як інтелектуальна власність.

Політика у сфері інтелектуальної власності є складовою частиною економічної політики, тобто ї̈ враховують у процесі підготовки й укладання угод про асоціацію. Запровадження принципів вільної ринкової економіки для сфери інтелектуальної власності має відправне значення з огляду на значною мірою транскордонний характер реалізаціі результатів інтелектуальної, творчої діяльності в певних об’єктах матеріального світу. У галузі захисту інтелектуальної власності, згідно з положеннями ст. ст. 161, 221, 228 Угоди про асоціацію, сторони діють відповідно до норм міжнародних конвенцій, зокрема положень ст. ст. 1-18 Бернської конвенції про охорону літературних і художніх творів (Берн, 1886 р., переглянута у 1979 р.), ст. ст. 1-22 Міжнародної конвенції про охорону прав акторіввиконавців, виробників фонограм й органів радіомовлення (Рим, 1961 р.), ст. 123 Угоди BOIC щодо виконання і фонограм (1996), ст. ст. 1-14 Угоди BOIC щодо авторських прав (1996), Конвенції щодо біологічної різноманітності (1992), Міжнародної конвенціï про захист нових сортів рослин (1961, переглянута в Женеві у 1972, 1978 та 1991 рр.).

Україна, окрім приєднання до положень та імплементації міжнародних конвенцій у сфері захисту прав інтелектуальної власності, має вдосконалити власний правовий механізм, що здатний на національному рівні забезпечити ефективний захист права на інтелектуальну власність [6]. В Угоді про асоціацію у гл. 9 «Інтелектуальна власність», а також у додатках до угоди містяться положення, націлені на уніфікацію національного законодавства 3 європейським та запровадження європейських стандартів захисту й охорони прав інтелектуальної власності у національне правозастосування. Варто погодитися

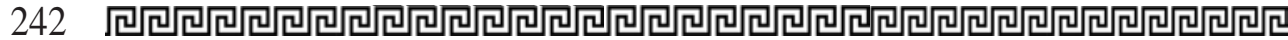


з О. Кадєтовою, що така уніфікація $€$ історичним процесом, обумовленим, з одного боку, прагненням усунути будь-які територіальні перешкоди щодо конкуренції в торгівлі, а з іншого боку, підвищенням рівня дотримання прав творців об'єктів інтелектуальної власності [7].

Ми погоджуємося з думкою О. Кадєтової [7] про те, що стосовно вирішення спорів із порушення прав інтелектуальної власності підкреслюється роль acquis communautaire в українській судовій практиці й доводиться необхідність застосування положень Угоди про асоціацію між Україною і ЄC стосовно прав інтелектуальної власності як норм прямої дії. Зазначений висновок обгрунтовується європейською судовою практикою, положеннями теорії права, міжнародного та цивільного права.

Цілями гл. 9 «Інтелектуальна власність» Угоди про асоціацію є такі:

- досягнення належного й ефективного рівня захисту та охорони прав інтелектуальної власності,

- спрощення створення та комерційного використання на територіi сторін інноваційних продуктів і продуктів творчої діяльності.

Глава містить також положення щодо авторського права й суміжних прав, торговельних марок, промислових зразків (зокрема, незареєстрованих), патентів на винаходи та географічних зазначень, що оновлюють і доповнюють Угоду СОТ у царині прав інтелектуальної власності, а також стосуються торгівлі. Глава має добре виписану частину щодо застосування прав інтелектуальної власності, що базується на внутрішніх правилах ЄC. Окрім приєднання та імплементації міжнародних конвенцій у сфері захисту прав інтелектуальної власності, в Угоді про асоціацію з ЄС Україна має створити правовий механізм, здатний забезпечити на національному рівні ефективний захист права інтелектуальної власності. Прямо в тексті Угоди про асоціацію подано перелік правових норм, що покладають на українську владу зобов'язання стосовно режиму використання об'єктів інтелектуальної власності й охорони та захисту прав інтелектуальної власності на теритоpii України. До законодавчих новел, що визначені у гл. 9 «Інтелектуальна власність» Угоди про асоціацію щодо захисту авторського та суміжного права, належать такі:

- досягнення ефективного рівня охорони й захисту прав інтелектуальної власності, забезпечення Україною ефективного захисту від недобросовісної конкуренціі;

- спрощення створення та комерційного використання інноваційних продуктів та продуктів творчої діяльності на території сторін.

Досить важливим аспектом розвитку правової думки в окресленому напрямі дослідження $€$ теоретичний аналіз досвіду зарубіжних країн. Країни, що здійснюють охорону інтелектуальної власності, класифікуються за різними підставами. У пропонованій статті за основу візьмемо класифікацію залежно від концепції охорони інтелектуальної власності (зокрема, авторського права й суміжних прав), що обумовлена приналежністю до певної правової сім’ї.

Відповідно до вибраного критерія, у країнах романо-германської правової сім’і право представлено нормами, що мають законодавче вираження (у вигляді кодексу або закону), а правозастосовувач порівнює конкретну ситуацію із загальною нормою і в ній знаходить вирішення справи. Всередині романо-германської правової сім’і виокремлюють групу романського права (Франція, Іспанія, Італія, Португалія, Бельгія, Швейцарія, Румунія, латиноамериканські країни) і групу німецького права (Німеччина, Угорщина, Австрія, скандинавські країни) [8]. Європейські держави свою правову систему перенесли в колоніальні володіння в Америці, Африці та Азіі. Окремі держави 
добровільно сприйняли конструкції, поняття й навіть цілі галузеві масиви 3 романо-германського права. Нині до романо-германської правової сім’і входить право країн континентальної Західної Європи, переважно держав Центральної та Південної Америки (колишніх колоній Португалії, Франціï та Іспаніi), право Південної Кореї, Японії, Індонезії, Таїланду та інших азіатських країн. Деякі вчені зауважують, що в Японії, Лівані, Непалі паралельно діють як прийняті елементи романо-германської правової моделі, так і традиційні норми, що склалися в цих країнах у минулому. Правові системи країн Близького й Середнього Сходу, а також багатьох африканських держав тяжіють до романо-германського права.

Країни англосаксонської правової системи утворюють другу велику правову сім'ю. До англосаксонської правової системи входять такі країни, як США, Велика Британія, Канада, Нова Зеландія, Індія, Австралія. Для цієі правової сім’ї характерно одночасне існування прецедентного і статутного права (система нормативно-правових актів). Головним джерелом англосаксонського права $є$ судовий прецедент. Для англосаксонської системи права характерний казуальний тип юридичної свідомості, а не нормативний: факт тут порівнюють не з нормативною моделлю, а з іншим аналогічним казусом, правозастосовною та судовою практикою. Авторське право у країнах 3 англо-американськими юридичними традиціями (сім`ї загального права) позначається терміном "copyright" (букв. - «право на відтворення» або «право на копію»). Сукупність зазначених норм у країнах континентальної європейської юридичної традиції (романо-германської групи) називають “droitd'auteur" (у пер. із франц. «право автора»), “pro prietelitteraireetartistique" (у пер. із франц. «літературна і художня власність»), "Urheberrecht” (у пер. $з$ нім. «авторське право»). Континентальне право автора має особистісну орієнтацію, а англо-американське право на копію - комерційну. Правова охорона, поширена у країнах англо-американської правової сім’ї, покликана заохочувати створення нових творів.

Наділяючи автора невідчужуваними моральними правами, романо-германська система використовує особистісний підхід, за якого інтереси творця твору мають дотримуватися насамперед хоча б тому, що саме він є ключовою фігурою всієї системи, що дала назву зазначеній галузі права. Сфера юридичної регламентації мистецтва у континентальній системі чітко розділяється на інститут, що охороняє мистецькі твори (авторське право), й інститут, що захищає виконання цих творів артистами, а також фонограми (суміжні права). Частина перша законодавчої частини Кодексу інтелектуальної власності Франції присвячена питанням авторського права й суміжних прав, ii положення зібрані у трьох томах. Другий том першої частини Кодексу присвячено суміжним правам (права артистів-виконавців, підприємств аудіовізуального мовлення, виробників фонограм і відеограм), а об'єктам промислової власності присвячена частина друга законодавчої частини Кодексу інтелектуальної власності Франціі. Поділ авторських та суміжних прав існує також у Німеччині. Це зафіксовано у змісті федерального закону «Про авторські і суміжні права» від 9 вересня 1965 р. Розмежування режимів охорони художніх творів і виконань фонограм у англо-американській правовій системі не здійснюється. Це приводить до того, що авторське право країн системи "copyright" застосовують до цінностей, які можуть і не бути творчими творами. Для позначення способів використання твору у країнах романо-германської групи використовують синтетичний метод [9]. Його сутність полягає в тому, що за автором визнано обмежену кількість 
правочинів, які трактуються в доктрині або судами найширшим чином (наприклад, у Франціï). У німецькому праві представлено напівсинтетичний підхід. У ньому майнове авторське право підрозділяється на дві широкі правомочності, такі як право використовувати твір у матеріальній формі і право на публічне повідомлення твору в нематеріальній формі ( 15 Закону про авторське право). Ці широкі за змістом права уточнені в зазначеному документі шляхом перерахування конкретних правомочностей (\$ 16-22).

У країнах англо-американської системи використовують аналітичний метод. У законодавстві представлено довгий перелік, що містить усі відомі на певний момент часу способи використання твору, кожному з яких відповідає конкретна правомочність. Зазвичай ці правомочності трактуються судами буквально. Такий шлях вписується в логіку загального права, що уникає занадто абстрактних визначень. До переваг цього методу належить його точність, а недоліками $€$ безсистемність і нееластичність. Використання такого клаптикового методу породжує ситуацію, за якої правомочності обов'язково починають змішуватися, витісняти одна одну. У Великій Британії та Канаді, наприклад, передбачено кримінальну відповідальність як за відтворення (видання) твору (або виготовлення піратської копіі), так і за виготовлення пристрою для творення копій або володіння ним.

Однак не можна стверджувати, що у США та Великій Британії зовсім відсутні механізми охорони особистого немайнового інтересу автора. Особисті немайнові права (право авторства на оприлюднення твору та його назву, на недоторканність твору) в механізмі авторського права розглядаються у взаємозв'язку з майновими інтересами автора. Наявні у країнах англосаксонської правової системи механізми охорони немай- нових інтересів авторів несиметричні континентальним аналогам. У США i Великій Британії статутне закріплення конструкціі моральних прав стало політичним компромісом, продиктованим інтересами експорту інтелектуальної власності цими країнами, а не результатом свідомого вибору. Проте правова охорона тільки майнової складової частини інтелектуальної власності існує в деяких країнах романо-германської групи. Правова охорона особистих немайнових прав у цих країнах обумовлена нанесенням автору майнової шкоди або розміром вигоди, отриманої злочинцем [10]. Отже, слід підкреслити, що для отримання інформації про кримінально-правову охорону інтелектуальної власності в тій чи іншій країні одних знань, до якої правової сім’і вона належить, недостатньо. У законодавстві країн, що належать до однієї правової системи, є істотні відмінності в механізмах правової охорони інтелектуальних прав (причини виникнення цих відмінностей можуть бути темою окремого дослідження).

Висновки. Розбіжності міжнародно-правової охорони інтелектуальної власності, зазначені у статті, підводять до висновку про доцільність уніфікації розглянутих норм. Проте навіть певне зближення законодавства різних країн у галузі охорони авторського права, що відбулося впродовж останніх 130 років, є дискусійним, що не гарантує успіху такого проєкту. Основною причиною цього $€$ наявність відмінностей у національному авторському праві різних країн, обумовлених їхніми економічними інтересами, що часто суперечать один одному. Тоді як розвинені країни, що $€$ виробниками об'єктів інтелектуальної власності, зацікавлені у збільшенні юридичних засобів іiі захисту, країнам, що розвиваються, які споживають ці об'єкти, навпаки, вигідне послаблення правової охорони. Ще однією важливою проблемою $є$ відсутність єдиного судового органу, що 
забезпечив би однакову практику навіть у разі здійснення уніфікації національних норм.

Наступним висновком, на який слід звернути увагу, є те, що у країнах романо-германської правової сім’ї концепція правової охорони інтелектуальної власності відрізняється від підходу, прийнятого у країнах англо-американської правової системи. Однак для отримання даних про правову охорону інтелектуальної власності в конкретній країні мало знати, до якої правової сім’ї вона належить. У законодавстві країн, що входять до однієї правової системи, спостерігаються істотні відмінності в механізмах правової охорони інтелектуальних прав. Причини виникнення зазначених відмінностей можуть бути темою окремого дослідження.

У деяких зарубіжних країнах, зокрема в Казахстані, Китаї, Азербайджані, Киргизстані, Вірменії, Туркменістані, Молдові, Угорщині, правовій охороні підлягає лише майнова складова частина інтелектуальної власності. У другій групі країн, серед яких слід назвати США, Велику Британію, Канаду, Німеччину, Францію, Австралію, Грецію, Іспанію, Італію, Японію, Грузію, Білорусь, Бельгію, Албанію, Болгарію, Голландію, Латвію, Литву, Норвегію, Сан-Марино, Таджикистан, Туреччину, Узбекистан, Швецію, Естонію, правовій охороні підлягають як майнові, так і немайнові права авторів та правовласників.

Серед оптимальних варіантів урегулювання проблеми конкуренції норм міжнародного права у сфері охорони інтелектуальної власності можемо запропонувати такі пріоритетні напрями:

- колізійний підхід до вирішення проблеми множинності застосовного права, що, на нашу думку, є найбільш привабливим, оскільки спирається переважно на наявні норми, не вимагаючи кардинальної зміни національного законодавства;
- за неможливості прив'язати правопорушення, вчинене в Інтернеті, до конкретного місця його здійснення, пропонуємо застосувати правило lex loci delicti, тобто взяти за основу місце, де перебував порушник у момент правопорушення; такий підхід має певну перспективу, оскільки дає змогу дуже легко визначити застосовне право в кожному конкретному випадку;

- гармонізація міжнародного законодавства, зокрема на рівні великих субрегіонів (США, ЄС, Тихоокеанський регіон тощо); така гармонізація може відбуватися на рівні директив, які роз'яснила б і за необхідності осучаснила Директива 2001/29/EC Європейського парламенту та Ради Європейського Союзу «Про гармонізацію деяких аспектів авторського права і суміжних прав в інформаційному суспільстві» 2001 р.

у статті досліджено міжнародно-правові аспекти охорони інтелектуальної власності. Зазначено, щз з розвитком інформаційних правовідносин та інформаційно-комунікаційних технологій правова охорона інтелектуальної власності значно модернізувалась, адже змінилась кониепція юридичної відповідальності, виникли нові правовідносини, нові об'єкти правової охорони тощо. Як одну з актуальних проблем у зазначеному контексті виокремлено конкуренцію міжнародно-правових норм охорони інтелектуальної власності.

Серед оптимальних варіантів урегулювання проблеми конкуренції норм міжнародного права у сфері охорони інтелектуальної власності у статmі запропоновано колізійний підхід до вирішення проблеми множинності застосовного права; за неможливості прив'язати правопорушення, учинене в Iнтернеті, до конкретного місия його здійснення застосування правила lex loci delicti; гармонізація міжнародного законодавства, зокрема на рів- 
ні великих субрегіонів (США, ЄС, Тихоокеанський регіон тощо).

У статті досліджено досвід окремих країн із правової охорони інтелектуальної власності. Зроблено висновок, шо у країнах романо-германської правової сім'ї концепція правової охорони інтелектуальної власності відрізняеться від підходу, прийнятого у країнах англо-американської правової системи. Однак для отримання даних про правову охорону інтелектуальної власності в конкретній країні мало знати, до якої правової сім'ї вона належить. У законодавстві країн, що входять до однієї правової системи, спостерігаються істотні відмінності в механізмах правової охорони інтелектуальних прав. Така гармонізація може відбуватися на рівні директив, які роз'яснила б $і$ за необхідності осучаснила Директива 2001/29/EC Європейського парламенту та Ради Европейського Союзу «Про гармонізацію деяких аспектів авторського права і суміжних прав в інформаuійному суспільстві» 2001 p.

Ключові слова: інтелектуальна власність, правова охорона, авторське право.

Kostyuchenko Ya. International legal aspects of protection of intellectuality of property: experience, legal regulation, prospects for national practice

The article examines the international legal aspects of intellectual property protection. It is noted that with the development of information relations and information and communication technologies, the legal protection of intellectual property has been significantly modernized - the concept of legal liability has changed, new legal relations, new objects of legal protection, etc. One of the current problems in this context is the competition of international legal norms for the protection of intellectual property.
Among the best options for resolving the problem of competition of international law in the field of intellectual property protection, the article proposes: a conflicting approach to solving the problem of plurality of applicable law; if it is impossible to link an offense committed on the Internet to a specific place of its commission, it is proposed to apply the rule lex loci delicti; harmonization of international legislation, in particular at the level of large subregions (USA, EU, Pacific region, etc.).

The article examines the experience of individual countries in the legal protection of intellectual property. It is concluded that in the countries of the Romano-Germanic legal family the concept of legal protection of intellectual property differs from the approach adopted in the countries of the Anglo-American legal system. However, in order to obtain data on the legal protection of intellectual property in a particular country, it was necessary to know to which legal family it belongs. In the legislation of the countries that are part of the same legal system, there are significant differences in the mechanisms of legal protection of intellectual property rights. Such harmonization can take place at the level of directives, which would be clarified and, if necessary, updated by Directive 2001 / 29 / EC of the European Parliament and of the Council of the European Union "On the harmonization of certain aspects of copyright and related rights in the information society" of 2001.

Key words: intellectual property, legal protection, copyright.

\section{Література}

1. Beijing Treaty on Audiovisual Performances. June 24, 2012. WIPO. URL: https: / / www.wipo.int/treaties / en/ip / beijing.

2. Geneva Act of the Lisbon Agreement on Appellations of Origin and Geographical Indications. of May 20 2015. WIPO. URL: 
https: / / ww.wipo.int / edocs / pubdocs / en /wipo_pub_239.pdf.

3. The Marrakesh Treaty to Facilitate Access to Published Works for Persons Who Are Blind, Visually Impaired, or Otherwise Print Disabled. June 27, 2013. WIPO. URL: https: / / www.wipo.int / edocs / mdocs / copyright/en/wipo_cr_mow_17/wipo_cr_ mow_17_topic_2_c.pdf.

4. Gervais D.J. Is there a "middle way" in international intellectual property? IIC International review of intellectual property and competition law. Munich, 2016. Vol. 47. No. 2. P. 135-137.

5. Угода про асоціацію між Україною, з однієї сторони, та Європейським Союзом, Європейським співтовариством з атомної енергї $і$ іхніми державами-иленами, з іншої сторони. Редакиія від 30 листоnada 2015 p. URL: https: //zakon.rada. gov.ua/laws/show/984_011\#Text.

6. Муравйов В. Правовий механізм реалізації Угоди про асоціацію між Україною та Європейським Союзом. Віче. 2015. № 4. C. 25-29.
7. Кадєтова О. Реформа інтелектуальної власності в Україні через призму європейської правової доктрини інтелектуальної власності. Теорія $і$ практика інтелектуальної власності. 2017. № 3. C. $77-86$.

8. Жак А. Порівняльно-правовий аналіз джерел (форм) права романо-германської правової системи та англосаксонської правової сім'ї. Juris Europensis Scientia. 2020. Bun. (2). C. 97-102. URL: https: / / doi.org / 10.32837/chern. v0i2.82.

9. Правове забезпечення сфери інтелектуальної власності в Україні в контексті Європейської інтеграції: конuептуальні засади : монографія / ред. О. Орлюк. Київ : Лазурит-Поліграф, 2010. $464 \mathrm{c}$.

10. The Most Innovative Tech Companies Based On Patent Analytics. URL: https://www.forbes.com/sites / louiscolumbus / 2019/12/15/the-mostinnovativetech-companies-based-on-patentanalytics / \#3665b9e762ce. 